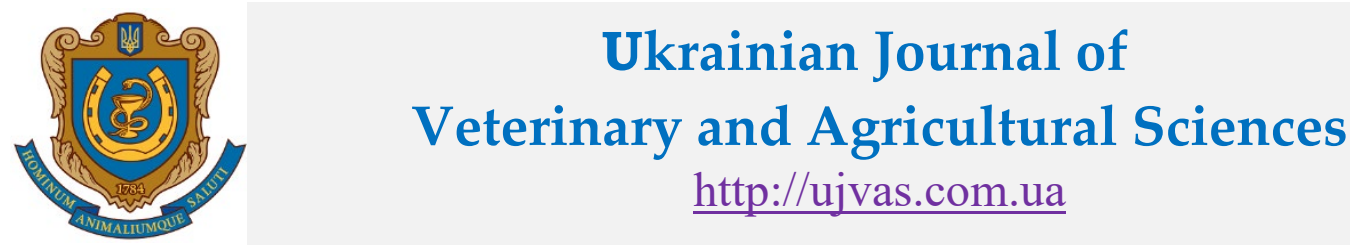

Stepan Gzhytskyi National University of Veterinary Medicine and Biotechnologies Lviv

\begin{tabular}{l|l|l} 
original article & UDC 619:616-092:612.017:636.4 & doi: 10.32718/ujvas3-2.09
\end{tabular}

Volume 3

Number 2

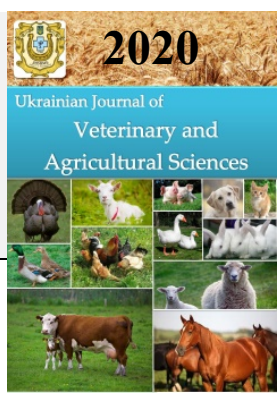

\title{
Antioxidant status of piglets under nitrate-nitrite load and the action of corrective factors
}

\author{
K. Y. Leskiv ${ }^{1}$, B. V. Gutyj ${ }^{1}$, D. F. Gufriy ${ }^{1}$, V. I. Khalak ${ }^{2}$, O. G. Demchuk ${ }^{1}$

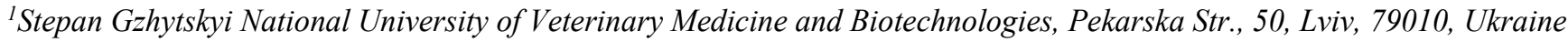 \\ ${ }^{2}$ State Institution Institute of grain crops of NAAS, V. Vernadsky Str., 14, Dnipro, 49027, Ukraine
}

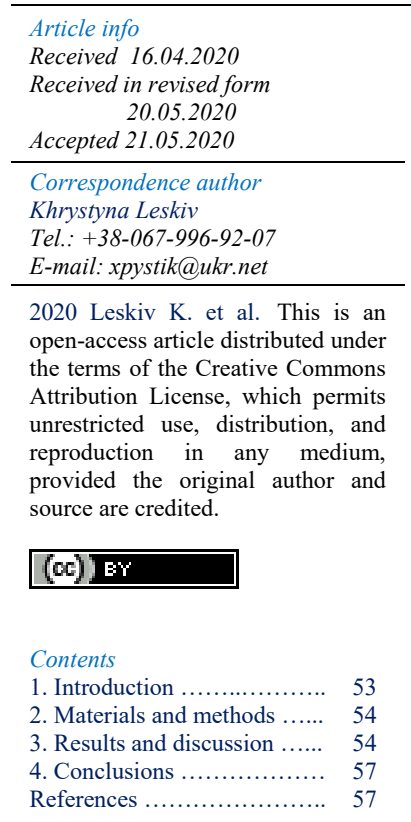

\begin{abstract}
The article presents the results of research on the state of the antioxidant defense system of piglets under nitratenitrite toxicosis and the action of corrective factors (methionine, phenarone and methyphene). Nitrate-nitrite load in piglets caused inhibition of the activity of enzymes of the antioxidant defense system, that indicates a decrease in the activity of superoxide dismutase, catalase and glutathione peroxidase in the serum of testing animals. The lowest activity of antioxidant enzymes under chronic nitrate-nitrite toxicosis was on the 60th day of the experiment in the serum of piglets of the control group, where accordingly the activity of superoxide dismutase decreased by $14 \%$, catalase activity - by $18 \%$, glutathione peroxidase activity - by $12 \%$. Lipid peroxidation processes are activated in the blood of animals, namely the level of lipid hydroperoxides and diene conjugates increases under the conditions of experimental nitrate-nitrite load. It should be noted that the highest level of lipid peroxidation products in the serum of piglets with chronic nitrate-nitrite toxicosis was on the 60 th day of the testing, and accordingly the content of lipid hydroperoxides increased by $67 \%$ and diene conjugates - by $33 \%$. Administration of methionine, phenarone and methyphene under nitrate load contributed to the activation of the antioxidant defense system compared to animals in the control group. The use of antioxidant drugs in sick piglets also contributed to the inhibition of lipid peroxidation, as indicated by a decrease in the content of lipid hydroperoxides and diene conjugates in the serum of experimental group. More pronounced antioxidant effect was shown by administrating methyphene. The mechanism of action of phenarone and methyphene is associated with the direct effect of its components on the inhibition of the absorption of metabolites that have a toxic effect on cell membranes of animals. As a result of the adsorbing action of zeolite, which is part of the drugs, in the digestive tract there is a decrease in the concentration of substances that can be substrates for lipid peroxidation, as well as removal of toxic metabolites in the blood, which are prooxidants. This process occurs by osmosis and diffusion of these substances through the capillaries of the microvilli of the small intestine and their subsequent fixation on the sorbent granules.
\end{abstract}

Key words: toxicology, antioxidant defense system, nitrates, nitrites, piglets.

\section{Citation:}

Leskiv, K. Y., Gutyj, B. V., Gufriy, D. F., Khalak, V. I., \& Demchuk, O. G. (2020). Antioxidant status of piglets under nitrate-nitrite load and the action of corrective factors. Ukrainian Journal of Veterinary and Agricultural Sciences, 3(2), 53-59.

\section{Introduction}

A significant number of scientific works of Ukrainian and foreign researchers are devoted to the study of issues related to nitrate-nitrite toxicosis of animals and poultry. These scientists have revealed the main links in the pathogenesis of nitrate-nitrite toxicosis with different course in animals and birds. In particular, the peculiarities of metabolic processes, violation of physiological functions of the body have been established (Douglas, 1970; Horner, 1982; Nordkvist et al., 2004; Aslani \& Vojdani, 2007; Issi et al., 2008; Gutyj et al., 2016a).

The action of nitrates on the body of animals is accompanied by the formation in the blood of methemoglobin, where iron (II) of hemoglobin is oxidized to iron (III) (Hegesh \& Shiloah, 1982; Saito et al., 1996; Robert et al., 1999; Harvey et al., 2010; Katabami et al., 2016). The pro- cess of oxidation of this blood protein is realized through the interaction of its oxyform with the nitrite ion in a chain path. During the oxidation of hemoglobin, a number of radical metabolites are formed, which are active oxidants of biological substrates and show a pronounced cytotoxic effect, initiating the processes of lipid peroxidation (LPO) (Hariv \& Gutyj, 2016; Gutyj et al., 2017a; 2017b). In the process of oxidation of oxyhemoglobin, active forms of oxygen are included as direct participants in the elementary stages, producers of toxic to the body hydrogen peroxide, which also participate in the oxidation reactions of oxyhemoglobin. The so-called oxidative stress develops (Khariv et al., 2016). It occurs when the action of prooxidant factors exceeds the activity of the antioxidant defense system. The main impetus for this process, regardless of the specifics of the lesion and the associated source of activation of the LPO, is excessive, 
primary or secondary, activation of free radical reactions (Todoriuk et al., 2017).

The protection of the animal's body from reactive oxygen species and toxic products of their metabolism is provided by the antioxidant defense system. If the active oxygen metabolites are not sufficiently eliminated, the oxidative stress that occurs under these conditions can cause peroxide damage to cell membranes and intracellular biopolymers (proteins, nucleic acids). In addition, changes in cell membranes and cell components induced by active oxygen metabolites can modify metabolic pathways and affect physiological processes in animal tissues (Gutyj et al., 2016b; Martyshuk et al., 2016).

Nitrate poisoning kills productive livestock of farm animals, especially piglets after weaning, and causes significant economic damage (Todoriuk et al., 2016). Therefore, indepth study of the pathogenesis of nitrate-nitrite toxicosis in pigs and methods of its correction is extremely important (Medeiros et al., 2003).

The aim of the work is to establish the state of the antioxidant system of the body of piglets under the conditions of nitrate-nitrite toxicosis and the action of corrective factors (methionine, phenarone and methyphene).

\section{Materials and methods}

To perform the experimental work, the studies were performed on large white piglets of three months of age. During the research, the rules mandatory for zootechnical experiments on the selection and keeping of analogue animals in groups were followed.

All animal manipulations were carried out following the European Convention on the protection of vertebrate animals used for experimental and scientific purposes (Strasbourg, 1986) and the "General ethical principles of animal experimentation," adopted by the first national congress on bioethics (Kyiv, 2001). The experiments were carried out in accordance with the principles of humanity set out in the European community directive.

Four groups of animals were formed: control (C) and three experimental groups (E). Piglets of group $\mathrm{C}$ were fed for three months $\mathrm{NaNO}_{3}$ at a dose of $0.3 \mathrm{~g} \mathrm{NO}_{3}{ }^{-} / \mathrm{kg}$ bw/day. Animals of group $\mathrm{E}_{1}$ were fed $\mathrm{NaNO}_{3}$ at a dose of $0.3 \mathrm{~g}$ $\mathrm{NO}_{3}{ }^{-} / \mathrm{kg}$ bw/day together with methionine at a dose of $4 \mathrm{mg} / \mathrm{kg}$ bw/day for three months. Animals of group $\mathrm{E}_{2}$ were fed $\mathrm{NaNO}^{3}$ at a dose of $0.3 \mathrm{~g} \mathrm{NO}^{3-} \mathrm{kg}$ bw/day together with phenarone at a dose of $1.2 \mathrm{mg} / \mathrm{kg}$ bw/day, for three months. Animals of group $\mathrm{E}_{3}$ were fed with feed $\mathrm{NaNO}_{3}$ at a dose of $0.3 \mathrm{~g} \mathrm{NO}^{3-} / \mathrm{kg} \mathrm{bw} /$ day with methyphene at a dose of $0.9 \mathrm{mg} / \mathrm{kg} \mathrm{bw} /$ day for three months.
Methionine - Methioninum, a white crystalline powder with a specific odor with an active substance content of at least $98.5 \%$. Well soluble in dilute mineral acids, caustic alkalis and ammonia, sparingly soluble in water.

Phenarone - Fenaronum, is a complex compound containing $70 \%$ phenazanoic acid and $30 \%$ zeolite. Poorly soluble in cold water, better - in hot water. Thermostable.

Methyphene - Methiphenum; white crystalline powder, sweet to the taste, with the smell of sulfur. Poorly soluble in cold water, better - In hot water $(1: 20)$. Thermostable. The drug contains phenarone and methionine.

Venous blood was collected at the beginning of the experiment and on the 10th, 30th, 60th and 90th days of the experiment. In blood serum investigated: the glutathione peroxidase activity - GPO (E.C.1.11.1.9; Moin V. M., 1986); the catalase activity - CT (E.C. 1.11.1.6; Korolyk M.A. and co-authors, 1988); the superoxide dismutase activity -SOD (EC 1.1.15.1. Dubynina E. E., 1983); the concentration of lipid hydroperoxides - LH (Myronchyk V. V., 1984); the level of diene conjugates - DC (Stalna I. D., 1977) (Vlizlo, 2012).

The Statistica 6.0 software package was performed for analysis of the research. The reliability of the difference between the groups was assessed by Student's t-test. The results were considered plausible at ${ }^{*}-\mathrm{P} \leq 0.05$.

\section{Results and discussion}

Oxidative stress is accompanied by an imbalance between the intensity of free radical oxidation processes and the system of antioxidant protection (Martyshuk et al., 2019a; 2019b; Grymak et al., 2020). The main radical that triggers the lipid peroxidation reaction in nitrate-nitrite toxicosis in piglets is a superoxide radical, so it is important to study superoxide dismutase, which dismantles this radical to less toxic hydrogen peroxide. It is known that superoxide dismutase is one of the key enzymes of antiradical protection, which is a direct-acting antioxidant (Gutyj et al., 2018; Martyshuk et al., 2018; Martyshuk \& Gutyj, 2019a; 2019b; Slobodian \& Hutyi, 2020).

In chronic nitrate-nitrite toxicosis in piglets found a reduction in the activity of this enzyme, starting from the 10 th day of the experiment, where it was respectively $31.14 \pm 0.17 \mathrm{SU} / \mathrm{mg}$ of protein (table 1 ). On the 30 th day of the testing, the activity of SOD decreased by $11 \%$ relative to baseline. On the 60th day of the experiment in animals treated with sodium nitrate in a subtoxic dose, the lowest activity of the enzyme in the serum was found, which was $28.51 \pm 0.15 \mathrm{SU} / \mathrm{mg}$ of protein.

\section{Table 1}

The effect of methionine, phenarone and methyphene on the serum activity of superoxide dismutase in piglets under chronic nitrate-nitrite toxicosis $\mathrm{SU} / \mathrm{mg}$ of protein, $(\mathrm{M} \pm \mathrm{m}, \mathrm{n}=5)$

\begin{tabular}{cccccc}
\hline $\begin{array}{c}\text { Groups of } \\
\text { animals }\end{array}$ & Initial values & 10th day & 30th day & 60th day & 90 th day \\
\hline $\mathrm{C}$ & $33.31 \pm 0.11$ & $31.14 \pm 0.17$ & $29.76 \pm 0.17$ & $28.51 \pm 0.15$ & $28.99 \pm 0.15$ \\
$\mathrm{E}_{1}$ & $33.42 \pm 0.16$ & $31.79 \pm 0.15$ & $30.45 \pm 0.19$ & $30.24 \pm 0.15^{*}$ & $32.85 \pm 0.06^{* *}$ \\
$\mathrm{E}_{2}$ & $34.12 \pm 0.18$ & $32.13 \pm 0.21$ & $31.74 \pm 0.13^{*}$ & $30.96 \pm 0.06^{*}$ & $32.56 \pm 0.15^{* *}$ \\
$\mathrm{E}_{3}$ & $33.80 \pm 0.14$ & $32.43 \pm 0.06$ & $32.88 \pm 0.12^{* *}$ & $32.61 \pm 0.06^{* *}$ & $33.11 \pm 0.05^{* *}$ \\
\hline
\end{tabular}


With the addition of methionine, phenarone and methyphene in piglets which were fed simultaneously the sodium nitrate at a dose of $0.3 \mathrm{~g} \mathrm{NO}_{3}{ }^{-} / \mathrm{kg}$ bw/day, prevented a decrease in superoxide dismutase activity, as indicated by the results of the studies shown in table 1. In animals of the experimental group, which were fed methionine, the activity of superoxide dismutase on the tenth day was $31.79 \pm 0.15 \mathrm{SU} / \mathrm{mg}$ of protein, on the 30 th day of the testing, the activity of the enzyme increased by $2.3 \%$ relative to animals in the control group, and on the 60th day, respectively, raised to $6 \%$. On the 90 th day of the experiment, the activity of SOD reached its initial values.

With the addition of methionine, phenarone and methyphene in piglets together with sodium nitrate, the activity of superoxide dismutase on the 10th day of the experiment was respectively $32.13 \pm 0.21$ and $32.43 \pm 0.06 \mathrm{SU} / \mathrm{mg}$ of protein. On the 30 th day of the study, the activity of SOD rised, respectively, in piglets of $\mathrm{E}_{2}$ group by $6.7 \%$, and in $\mathrm{E}_{3}$ group - by $10.5 \%$. On the 60 th day of the testing, more pronounced changes in the activity of SOD were found. Its activity in the serum of piglets of $E_{2}$ group was $30.96 \pm 0.06 \mathrm{SU} / \mathrm{mg}$ of protein, in $\mathrm{E}_{3}-32.61 \pm$ $0.06 \mathrm{SU} / \mathrm{mg}$ of protein, whereas in animals of the control group it was $28.51 \pm 0.15 \mathrm{SU} / \mathrm{mg}$ of protein.

Therefore, the use of the above medicines increased the activity of superoxide dismutase in the blood of piglets subjected to nitrate-nitrite load, which may be due to the direct participation of these drugs in the neutralization of free radicals and lipid peroxidation products.

It should be noted, that it is important in the functioning of the enzymatic system of antioxidant defense of the body to establish a balance between SOD and catalase. The catalase catalyzes the cleavage of hydrogen peroxide to form water and oxygen.

The activity of catalase in the serum of piglets under conditions of chronic nitrate-nitrite toxicosis is shown in table 2. As can be seen from this table, the activity of catalase in the serum of animals of the control group on the 10th day of the experiment decreased slightly relative to the initial values. On the 30th day of the research, the activity of the enzyme fell off to $11 \%$, and on the 60th day of the analyze, respectively, by $18 \%$ relative to the values in the serum of piglets of the control group at the beginning of the experiment.

Application of methionine to experimental piglets, helped to increase the activity of catalase throughout the experiment. On the 30th day of the experiment, the activity of the enzyme in the serum of piglets of group $E_{1}$ was $1.16 \pm 0.07 \mathrm{nmol} / \mathrm{min} \times \mathrm{mg}$ of protein, whereas in animals of the control group $1.10 \pm 0.05 \mathrm{nmoles} / \mathrm{min}$ for $1 \mathrm{mg}$ of protein. On the 60th day of the testing, catalase activity increased by $9.8 \%$ compared with the piglets of the control group.

In piglets of the experimental group, which together with sodium nitrate were fed phenarone, we note similar changes in catalase activity, as in the first case. Thus, on the 10th day of the analyze, the activity of the enzyme increased by $5 \%$, on the 30 th day - by $8 \%$, on the 60 th day of the experiment, respectively - by $15 \%$ relative to the animals of the control group.

Better effect on the activity of catalase in the serum of piglets was carried out by feeding methyphene to animals of group $E_{3}$, as indicated by the results of the studies shown in table 2 . The catalase activity on the 10th day in the serum of experimental piglets was $1.25 \pm 0.05 \mathrm{nmoles} / \mathrm{min}$ for $1 \mathrm{mg}$ of protein, while on the 30th day the activity of the enzyme increased by $10 \%$ relative to the piglets of the control group. On the 60th day of the analyze we note the highest catalase activity in comparison with animals of all experimental groups and the control group. On the 90th day of the research, the activity of the enzyme reached initial values.

\section{Table 2}

The effect of methionine, phenarone and methyphene on the serum activity of catalase in piglets under chronic nitrate-nitrite toxicosis, nmoles/min for $1 \mathrm{mg}$ of protein $(\mathrm{M} \pm \mathrm{m}, \mathrm{n}=5)$

\begin{tabular}{cccccc}
\hline \multirow{2}{*}{$\begin{array}{c}\text { Groups of } \\
\text { animals }\end{array}$} & Initial values & 10th day & 30th day & 60th day & 90 th day \\
\cline { 2 - 6 } & $1.24 \pm 0.06$ & $1.16 \pm 0.04$ & $1.10 \pm 0.05$ & $1.02 \pm 0.14$ & $1.03 \pm 0.06$ \\
$\mathrm{C}$ & $1.23 \pm 0.07$ & $1.20 \pm 0.08$ & $1.16 \pm 0.07^{*}$ & $1.12 \pm 0.06^{*}$ & $1.15 \pm 0.06^{* *}$ \\
$\mathrm{E}_{1}$ & $1.27 \pm 0.08$ & $1.22 \pm 0.06^{*}$ & $1.19 \pm 0.08^{*}$ & $1.17 \pm 0.08^{* *}$ & $1.22 \pm 0.07^{* *}$ \\
$\mathrm{E}_{2}$ & $1.26 \pm 0.06$ & $1.25 \pm 0.05^{*}$ & $1.21 \pm 0.02^{*}$ & $1.20 \pm 0.05^{* *}$ & $1.24 \pm 0.05^{* *}$ \\
$\mathrm{E}_{3}$ & &
\end{tabular}

Increased catalase activity in serum indicates high activity of oxidation and reduction processes in piglets fed antioxidants (Aslani \& Vojdani, 2007; Gutyj et al., 2017; Lavryshyn et al., 2019).

The second major important part of the antioxidant system is the glutathione system, which consists of both enzymatic and non-enzymatic. An important enzyme that is part of this system is glutathione peroxidase, which protects the body of animals from oxidative damage. This enzyme catalyzes the reduction of lipid peroxides and the reduction of hydrogen peroxide to water. By its activity in the blood of animals, we can judge the glutathione system of antioxidant defense of the body as a whole.

With the development of chronic nitrate-nitrite toxicosis in the serum of piglets found a decrease in glutathione peroxidase activity (table 3 ).
At the beginning of the research, the activity of glutathione peroxidase in the serum of piglets of all experimental groups was within the values $35.49 \pm 0.07-35.64 \pm$ $0.16 \mathrm{nmoles} / \mathrm{min}$ for $1 \mathrm{mg}$ of protein. On the $10 \mathrm{th}$ day of the testing, the activity of the enzyme in the serum of animals of the control group decreased by $6.5 \%$, on the 30 th day, respectively - by $11 \%$ relative to the initial values. On the 60th day of the experiment, the activity of glutathione peroxidase in the serum of control animals was the lowest, and accordingly was $31.20 \pm 0.09 \mathrm{nmoles} / \mathrm{min}$ for $1 \mathrm{mg}$ of protein. On the 90th day of the research, an increase in the activity of the enzyme was found, which may be due to the body's ability to adapt to long-term intake of sodium nitrate. 
Table 3

The activity of glutathione peroxidase in the serum of piglets in chronic nitrate-nitrite toxicosis, nmoles/min for $1 \mathrm{mg}$ of protein $(\mathrm{M} \pm \mathrm{m}, \mathrm{n}=5)$

\begin{tabular}{cccccc}
\hline \multirow{2}{*}{$\begin{array}{c}\text { Groups of } \\
\text { animals }\end{array}$} & \multicolumn{5}{c}{ Research periods } \\
\cline { 2 - 6 } & Initial values & 10th day & 30th day & 60th day & 90th day \\
\hline $\mathrm{C}$ & $35.49 \pm 0.07$ & $33.18 \pm 0.06$ & $31.60 \pm 0.18$ & $31.20 \pm 0.09$ & $31.52 \pm 0.21$ \\
$\mathrm{E}_{1}$ & $35.64 \pm 0.16$ & $35.10 \pm 0.19^{*}$ & $33.82 \pm 0.05^{*}$ & $32.75 \pm 0.20^{*}$ & $34.37 \pm 0.18^{*}$ \\
$\mathrm{E}_{2}$ & $35.55 \pm 0.04$ & $35.51 \pm 0.05^{*}$ & $34.71 \pm 0.22^{*}$ & $34.12 \pm 0.07 * *$ & $35.12 \pm 0.13^{* *}$ \\
$\mathrm{E}_{3}$ & $35.50 \pm 0.07$ & $36.19 \pm 0.14^{*}$ & $35.43 \pm 0.12^{* *}$ & $35.34 \pm 0.22^{* *}$ & $35.51 \pm 0.12^{* *}$ \\
\hline
\end{tabular}

With the addition of methionine in the blood serum of piglets, the activity of glutathione peroxidase on the 10th day of the experiment was $35.10 \pm 0.19 \mathrm{nmoles} / \mathrm{min}$ for $1 \mathrm{mg}$ of protein, which is $6 \%$ higher than in animals of the control group. On the 30th day of the research, the activity of GPO in the serum of the animals of group $E_{1}$ relative to the control group was higher by $7 \%$, and on the 60 th day by $5 \%$, respectively. On the 90 th day of the experiment, the activity of the enzyme increased, but compared with the initial values was lower by $4 \%$.

Feeding phenarone and methyphene to piglets with sodium nitrate also rised glutathione peroxidase activity in their blood. Thus, in the serum of animals of the experimental group $\mathrm{E}_{2}$, the activity of GPO on the 10th day of the analysis was $35.51 \pm 0.05 \mathrm{nmoles} / \mathrm{min}$ for $1 \mathrm{mg}$ of protein, whereas in piglets of experimental group $\mathrm{E}_{3}$ the activity of the studied enzyme was $36.19 \pm 0.14$ nmoles $/ \mathrm{min}$ for $1 \mathrm{mg}$ of protein. On the 30th day of the testing, the activity of GPO in animals fed phenarone was higher by $10 \%$, and in piglets fed methyphene, by $12 \%$ relative to that in animals of the control group. On the 60 th day of the research, the activity of GPO in the serum of piglets was in group $E_{2} 34,12 \pm 0,07$ nmoles/min for $1 \mathrm{mg}$ of protein, in animals of experimental group $\mathrm{E}_{3}-35,34 \pm 0,22 \mathrm{nmoles} / \mathrm{min}$ for $1 \mathrm{mg}$ of protein, which is respectively 13 and $17 \%$ more than in the control group.

Therefore, the use of antioxidant drugs, namely: methionine, phenarone and methyphene helped to increase the activity of the enzymatic system of antioxidant defense of piglets, preventing the development of oxidative stress that occurs in chronic nitrate-nitrite toxicosis.

Various complications in the course of the disease can be avoided by timely blocking of the triggering mechanism of the pathology. This is due to the reduction of the intensity of lipid peroxidation in the body through the use of antioxidants that prevent the formation of free radicals that can damage the cell. That is why we applied methionine, phenarone and methyphene in our studies.

According to tables 4 and 5, the development of chronic nitrate-nitrite toxicosis is accompanied by rising processes of lipid peroxidation, as indicated by an increase in the level of lipid hydroperoxides and diene conjugates in the serum of experimental piglets.

Table 4 shows the data of studies of the content of lipid hydroperoxides in the blood plasma of piglets in chronic nitrate-nitrite toxicosis and the use of antioxidant drugs.

Feeding the piglets feed together with sodium nitrate at a dose of $0.3 \mathrm{~g} \mathrm{NO}^{-} / \mathrm{kg}$ caused the growth in the content of lipid hydroperoxides in the serum of piglets of the control group. Thus, on the 10th day of the experiment, the content of lipid hydroperoxides increased by $21 \%$ compared with the initial values. Subsequently, again found an increase in the content of the indicator under study, which on the 30th day of the research was $1.12 \pm 0.05 \mathrm{SU} / \mathrm{ml}$ On the 60th day of the experiment, the content of hydroperoxides in the serum of piglets of the control group increased by $67 \%$ compared to the initial values. On the 90th day of the analysis, the content of lipid hydroperoxides in the serum of piglets of group $\mathrm{C}_{1}$ decreased slightly compared to the values of the 60th day, but remained at a high level and amounted to $1.23 \pm 0.03 \mathrm{SU} / \mathrm{ml}$.

With the addition of methionine to piglets of $E_{1}$ group helped to reduce the toxic effects of nitrates on piglets. On the 10th day of the experiment, the content of lipid hydroperoxides decreased by $8 \%$ relative to that of piglets in the control group. On the 30th day of the research, the content of lipid hydroperoxides in the serum of $\mathrm{E}_{1}$ group was lower by $6 \%$ relative to that of piglets in the control group. On the 60th day of the analysis, the content of lipid hydroperoxides compared with the previous period of the study increased, but compared with animals in the control group decreased by $11 \%$. On the 90th day of the experiment, the content of the studied indicator was $0.99 \pm 0.02 \mathrm{SU} / \mathrm{ml}$.

\section{Table 4}

The effect of methionine, phenarone and methyphene on the content of lipid hydroperoxides in the serum of piglets in chronic nitrate-nitrite toxicosis, $\mathrm{SU} / \mathrm{ml}(\mathrm{M} \pm \mathrm{m}, \mathrm{n}=5)$

\begin{tabular}{cccccc}
\hline Groups of & \multicolumn{5}{c}{ Research periods } \\
\cline { 2 - 6 } animals & Initial values & 10th day & 30th day & 60th day & 90 th day \\
\hline $\mathrm{C}$ & $0.75 \pm 0.04$ & $0.91 \pm 0.05$ & $1.12 \pm 0.05$ & $1.25 \pm 0.04$ & $1.23 \pm 0.03$ \\
$\mathrm{E}_{1}$ & $0.70 \pm 0.01$ & $0.84 \pm 0.04 *$ & $1.05 \pm 0.04 *$ & $1.11 \pm 0.03 * *$ & $0.99 \pm 0.02 * *$ \\
$\mathrm{E}_{2}$ & $0.68 \pm 0.01$ & $0.80 \pm 0.03 * *$ & $0.87 \pm 0.02 * *$ & $0.99 \pm 0.02 * *$ & $0.86 \pm 0.03 * *$ \\
$\mathrm{E}_{3}$ & $0.73 \pm 0.07$ & $0.79 \pm 0.04 * *$ & $0.80 \pm 0.01 * *$ & $0.85 \pm 0.03 * *$ & $0.78 \pm 0.04 * *$ \\
\hline
\end{tabular}

In chronic nitrate-nitrite toxicosis, phenarone had a more pronounced effect on the inhibition of LPO processes than methionine, as indicated by the content of lipid hydroperoxides in the serum. Thus, on the 10th day of the research, the content of lipid hydroperoxides in the serum of piglets of the experimental group was lower by $12 \%$, on the 30th day $22 \%$ relative to the rate in piglets of the control group. On the 60th day of the experiment, the content of lipid hydrop- 
eroxides increased slightly compared to the previous study period and, accordingly, was $0.99 \pm 0.02 \mathrm{SU} / \mathrm{ml}$. On the 90th day of the analysis, the content of the studied indicator decreased by $30 \%$ relative to the values of animals in the control group.

The administration of methyphene contributed to a better antioxidant effect than the use of phenarone and methionine alone. The components of methyphene act as synergists and have a more pronounced effect on the inhibition of lipid peroxidation. Thus, in these periods of the experiment, the content of lipid hydroperoxides in the serum of animals of $E_{3}$ group was the lowest compared with animals of $E_{1}$ and $\mathrm{E}_{2}$ groups. On the 10th day of the research, the content of lipid hydroperoxides in the serum of animals of the experimental group $\mathrm{E}_{3}$ was lower by $13 \%$, on the 30 th day - by $29 \%$, on the 60 th day - by $32 \%$ relative to animals in the control group. On the 90th day of the experiment, the content of lipid hydroperoxides reached the limits of physiological values, and was $0.78 \pm 0.04 \mathrm{SU} / \mathrm{ml}$.

In chronic nitrate-nitrite toxicosis of piglets, the content of diene conjugates in their serum increased throughout the experiment. On the 10th and 30th day of the experiment, the content of diene conjugates in the serum of piglets of the control group increased by 9 and $27 \%$ relative to the values taken at the beginning of the research. On the 60th day of the experiment, the content of diene conjugates in the serum of animals of $\mathrm{K}$ group was the highest $-9.05 \pm 0.26 \mu \mathrm{mol} / \mathrm{l}$. On the 90th day of the experiment, the content of diene conjugates decreased slightly, but compared with the blood taken at the beginning of the experiment was higher by $29 \%$ (Table 5).

Feeding methionine, phenarone, and methyphene to piglets reduced serum diene conjugates with chronic nitratenitrite toxicosis. Thus, on the 10th day of the experiment, the content of the studied indicator relative to the animals of the control group was lower by 3,5 and $6 \%$, respectively. On the 30th day of the testing, the content of diene conjugates in the serum of animals of the experimental groups increased and accordingly amounted to animals of group $E_{1}$ $8.24 \pm 0.23 \mu \mathrm{mol} / 1$, animals of group $\mathrm{E}_{2} 7.93 \pm 0.21 \mu \mathrm{mol} / 1$ and in piglets of group $\mathrm{E}_{3} 7.34 \pm 0.21 \mu \mathrm{mol} / 1$.

\section{Table 5}

The effect of methionine, phenarone and methyphene on the content of diene conjugates in the serum of piglets in chronic nitrate-nitrite toxicosis, $\mu \mathrm{mol} / \mathrm{l}(\mathrm{M} \pm \mathrm{m}, \mathrm{n}=5)$

\begin{tabular}{cccccc}
\hline \multirow{2}{*}{$\begin{array}{c}\text { Groups of } \\
\text { animals }\end{array}$} & Initial values & 10th day & 30th day & 60th day & 90th day \\
\hline $\mathrm{C}$ & $6.81 \pm 0.11$ & $7.44 \pm 0.24$ & $8.66 \pm 0.22$ & $9.05 \pm 0.26$ & $8.99 \pm 0.24$ \\
$\mathrm{E}_{1}$ & $6.68 \pm 0.11$ & $7.23 \pm 0.24^{*}$ & $8.24 \pm 0.23^{*}$ & $8.58 \pm 0.21^{*}$ & $7.93 \pm 0.23^{* *}$ \\
$\mathrm{E}_{2}$ & $6.56 \pm 0.12$ & $7.06 \pm 0.22^{*}$ & $7.93 \pm 0.21^{*}$ & $8.01 \pm 0.28^{* *}$ & $7.24 \pm 0.29 * *$ \\
$\mathrm{E}_{3}$ & $6.51 \pm 0.23$ & $6.97 \pm 0.26^{*}$ & $7.34 \pm 0.21^{* *}$ & $7.56 \pm 0.27 * *$ & $6.80 \pm 0.25^{* *}$ \\
\hline
\end{tabular}

On the 60th day of the experiment in the serum of piglets fed methionine, the DC content was lower by $5 \%$, in piglets fed phenarone by $11 \%$, and in piglets fed methyphene by $16 \%$ relative to the values of animals in the control group.

Therefore, the studied drugs have antioxidant properties, resulting in the restoration of equilibrium in the complex AOS-LPO in chronic nitrate-nitrite toxicosis.

\section{Conclusions}

Feeding piglets with sodium nitrate at a dose of $0.3 \mathrm{~g}$ $\mathrm{NO}^{-} / \mathrm{kg}$ bw/day, caused inhibition of the activity of enzymes of the antioxidant defense system, as indicated by a decrease in the activity of superoxide dismutase, catalase and glutathione peroxidase in the serum of piglets. The lowest activity of antioxidant enzymes in chronic nitratenitrite toxicosis was on the 60th day of the research in the serum of piglets of the control group, where accordingly the activity of superoxide dismutase decreased by $14 \%$, catalase activity - by $18 \%$, glutathione peroxidase activity - by $12 \%$.

In chronic nitrate-nitrite toxicosis of piglets, the processes of lipid peroxidation in their body are activated, which is indicated by the increase in the level of primary and intermediate products of lipid peroxidation, namely: lipid hydroperoxides and diene conjugates. The highest level of lipid peroxidation products in the serum of piglets in chronic nitrate-nitrite toxicosis was on the 60th day of the experiment, where the content of lipid hydroperoxides increased by $67 \%$ and diene conjugates - by $33 \%$.
The use of methionine, phenarone and methyphene in piglets in chronic nitrate-nitrate toxicosis contributed to the activation of the antioxidant defense system compared to control animals. The use of antioxidant drugs in sick testing animals also contributed to the inhibition of lipid peroxidation, as indicated by a decrease in the content of lipid hydroperoxides and diene conjugates in the serum of experimental piglets. Feeding metifen piglets with a more pronounced antioxidant effect.

\section{Conflict of interest}

The authors declare that there is no conflict of interest.

\section{References}

Aslani, M. R., \& Vojdani, M. (2007). Nitrate intoxication due to ingestion of pig weed red-root (Amaranthus retroflexus) in cattle. Iranian Journal of Veterinary Research, 8, 377-380. doi: 10.22099/IJVR.2007.33.

Douglas, H. K. Lee (1970). Nitrates, nitrites, and methemoglobinemia. Environmental Research, 3(5-6), 484-511 doi: 10.1016/0013-9351(70)90042-3.

Grymak, Y., Skoromna, O., Stadnytska, O., Sobolev, O., Gutyj, B., Shalovylo, S., Hachak, Y., Grabovska, O., Bushueva, I., Denys, G., Hudyma, V., Pakholkiv, N., Jarochovich, I., Nahirniak, T., Pavliv, O., Farionik, T., Bratyuk, V. (2020). Influence of "Thireomagnile" and "Thyrioton" preparations on the antioxidant status of pregnant cows. Ukrainian Journal of Ecology, 10(1), 122-126. doi: 10.15421/2020_19.

Gutyj, B. V., Gufriy, D. F., Binkevych, V. Y., Vasiv, R. O., Demus, N. V., Leskiv, K. Y., Binkevych, O. M., \& Pavliv, O. V. (2018). Influence of cadmium loading on glutathione system of antioxidant protection of the bullocks'bodies. Scientific Mes- 
senger of Lviv National University of Veterinary Medicine and Biotechnologies, 20(92), 34-40. doi: 10.32718/nvlvet9207.

Gutyj, B. V., Hufriy, D. F., Hunchak, V. M., Khariv, I. I., Levkivska, N. D., \& Huberuk, V. O. (2016a). The influence of metisevit and metifen on the intensity of lipid per oxidation in the blood of bulls on nitrate load. Scientific Messenger LNUVMBT named after S.Z. Gzhytskyj, 18, 3(70), 67-70 doi: $10.15421 /$ nvlvet7015.

Gutyj, B. V., Murs'ka, S. D., Gufrij, D. F., Hariv, I. I., Levkivs'ka, N. D., Nazaruk, N. V., Gajdjuk, M. B., Pryjma, O. B., Bilyk, O. Ja., \& Guta, Z. A. (2016b). Vplyv kadmiievoho navantazhennia na systemu antyoksydantnoho zakhystu orhanizmu buhaitsiv [Influence of cadmium loading on the state of the antioxidant system in the organism of bulls]. Visnyk of Dnipropetrovsk University. Biology, ecology, 24(1), 96-102. doi: 10.15421/011611.

Gutyj, B., Khariv, I., Binkevych, V., Binkevych, O., Levkivska, N., Levkivskyj, D., \& Vavrysevich, Y. (2017b). Research on acute and chronic toxity of the experimental drug Amprolinsyl. Regulatory Mechanisms in Biosystems, 8(1), 41-45 doi: 10.15421/021708.

Gutyj, B., Martyshchuk, T., Bushueva, I., Semeniv, B., Parchenko, V., Kaplaushenko, A., Magrelo, N., Hirkovyy, A., Musiy, L., \& Murska, S. (2017a). Morphological and biochemical indicators of blood of rats poisoned by carbon tetrachloride and subject to action of liposomal preparation. Regulatory Mechanisms in Biosystems, 8(2), 304-309. doi: 10.15421/021748.

Gutyj, B., Leskiv, K., Shcherbatyy, A., Pritsak, V., Fedorovych, V., Fedorovych, O., Rusyn, V., \& Kolomiiets, I. (2017d). The influence of Metisevit on biochemical and morphological indicators of blood of piglets under nitrate loading. Regulatory Mechanisms in Biosystems, 8(3), 427-432. doi: 10.15421/021766.

Hariv, M. I., \& Gutyj, B. V. (2016). Vplyv liposomalnoho preparatu Butaintervit na proteinsyntezuvalnu funktsiiu pechinky shchuriv za otruiennia tetrakhlormetanom [Influence of the liposomal preparation Butaintervite on protein synthesis function in the livers of rats under the influence of carbon tetrachloride poisoning]. Visnyk of Dnipropetrovsk University. Biology, Medicine, 7(2), 123-126 doi: 10.15421/021622 (in Ukrainian).

Harvey, M., Cave, G., \& Chanwai, G. (2010). Fatal methaemoglobinaemia induced by self-poisoning with sodium nitrite. Emergency Medicine Australasia, 22(5), 463-465 doi: 10.1111/j.1742-6723.2010.01335.x.

Hegesh, E., \& Shiloah, J. (1982). Blood nitrates and infantile methemoglobinemia. Clinica Chimica Acta, 125(2), 107-115 doi: 10.1016/0009-8981(82)90187-5.

Horner, R. F. (1982). Suspected ammonium nitrate fertilizer poisoning in cattle. Veterinary Record, 110, 472-474. doi: 10.1136/vr.110.20.472.

Issi, M., Gul, Y., Atessahin, A., \& Karahan, I. (2008). Acute nitrate poisoning in two cattle. Toxicology and Environmental Chemistry, 90, 135-140 doi: 10.1080/ 02772240701365649.

Katabami, K., Hayakawa, M., \& Gando, S. (2016). Severe Methemoglobinemia due to Sodium Nitrite Poisoning. Case Reports in Emergency Medicine, 3 doi: 10.1155/2016/9013816.

Khariv, M., Gutyj, B., Butsyak, V., \& Khariv, I. (2016). Hematolohichni pokaznyky orhanizmu shchuriv za umov oksydatsiinoho stresu ta za dii liposomalnoho preparatu [Hematological indices of rat organisms under conditions of oxidative stress and liposomal preparation action]. Biological Bulletin of Bogdan Chmelnitskiy Melitopol State Pedagogical University, 6(1), 276-289. doi: 10.15421/201615 (in Ukrainian).

Lavryshyn, Y. Y., Gutyj, B. V., Paziuk, I. S., Levkivska, N. D., Romanovych, M. S., Drach, M. P., \& Lisnyak, O. I. (2019). The effect of cadmium loading on the activity of the enzyme link of the glutathione system of bull organism. Scientific Messenger of Lviv National University of Veterinary Medicine and Biotechnologies. Series: Veterinary sciences, 21(95), 107-111. doi: 10.32718/nvlvet9520.
Martyshchuk, T. V., \& Gutyi, B. V. (2019a). Influence of feed additive "Butaselmevit Plus" on the indicators of rats blood under the conditions of their poisoning with Tetrachloromethane. Theoretical and Applied Veterinary Medicine, 7(2), 79-83. doi: 10.32819/2019.71014.

Martyshuk, T. V., Gutyj, B. V., \& Vishchur, O. I. (2016). Riven produktiv perekysnoho okysnennia lipidiv u krovi shchuriv za umov oksydatsiinoho stresu ta za dii liposomalnoho preparatu "Butaselmevit" [Level of lipid peroxidation products in the blood of rats under the influence of oxidative stress and under the action of liposomal preparation of "Butaselmevit"]. Biological Bulletin of Bogdan Chmelnitskiy Melitopol State Pedagogical University, 6(2), 22-27 doi: 10.15421/201631 (in Ukrainian).

Martyshuk, T. V., Gutyj, B. V., \& Vishchur, O. I. (2018). Indicators of functional and antioxidant liver status of rats under oxidative stress conditions and on the action of the liposomal drug "Butaselmevit". Scientific Messenger of Lviv National University of Veterinary Medicine and Biotechnologies, 20(89), 100107. doi: $10.32718 /$ nvlvet 8919 .

Martyshuk, T. V., Gutyj, B. V., \& Vishchur, O. I. (2019b). Morphological and biochemical indices of piglets' blood by the action of feed additive "Butaselmevit-plus". The Animal biology, 21(4), 65-70. doi: 10.15407/animbiol21.04.065.

Martyshuk, T. V., Gutyj, B. V., Vishchur, O. I., \& Todoriuk, V. B. (2019a). Biochemical indices of piglets blood under the action of feed additive "Butaselmevit-plus". Ukrainian Journal of Veterinary and Agricultural Sciences, 2(2), 27-30. doi: 10.32718/ujvas2-2.06.

Martyshuk, T. V., \& Gutyj, B. V. (2019b). Influence of feed additive "Butaselmevit-Plus" on antioxidant status of rats in conditions of oxidative stress. Scientific Messenger of Lviv National University of Veterinary Medicine and Biotechnologies. Series: Agricultural sciences, 21(90), 76-81. doi: 10.32718/nvlveta9013.

Medeiros, R. M. T., Riet-Correa, F., Tabosa, I. M., Silva, Z. A., Barbosa, R. C., Marques, A. V. M. S., \& Nogueira, F. R. B. (2003). Intoxicação por nitratos e nitritos em bovinos por ingestão de Echinochloa polystachya (capim-mandante) e Pennisetum purpureum (capim-elefante) no sertão da Paraíba Nitrate and nitrite poisoning in cattle caused by the ingestion of Echinochloa polystachya and Pennisetum purpureum in the semiarid region of the state of Paraíba. Pesquisa Veterinária Brasileira, 23(1), 1720 doi: 10.1590/S0100-736X2003000100004.

Nordkvist, M., Rehbinder, C., Mukherjee, S. C., \& Erne, K. (1984). Pathology of acute and subchronic nitrate poisening in reindeer (Rangifer tarandus L). Rangifer, 4(1), 9-15 doi: $10.7557 / 2.4 .1 .486$.

Robert, O. W., William, J. L., \& Alan, D. W. (1999). Methemoglobinemia: etiology, pharmacology, and clinical management. Annals of Emergency Medicine, 34, 646-656 doi: 10.1016/S0196-0644(99)70167-8.

Saito, T., Takeichi, S., Yukawa, N., \& Osawa, M. (1996). Fatal methemoglobinemia caused by liniment solutions containing sodium nitrite. Journal of Forensic Sciences, 41(1), 169-171 doi: 10.1520/JFS13919J

Slobodian, S. O., \& Hutyi, B. V. (2020). Stan antyoksydantnoi systemy orhanizmu shchuriv $\mathrm{v}$ umovakh tryvaloho kadmiievoho i svyntsevoho navantazhennia. Visnyk PDAA, 1, 196-201. doi: 10.31210/visnyk2020.01.25.

Todoriuk, V. B., Hunchak, V. M., Hufrii, D. F., Hutyi, B. V., Khariv, I. I., Khomyk, R. I., Vasiv, R. O., Slobodiuk, N. M., Vyniarska, A. V., Zhuravlov, O. Iu., Husar, P. T., Nazaruk, N. V., Nazaruk, N. Ia., \& Soltys, M. P. (2017). Doslidzhennia hostroi ta khronichnoi toksychnosti eksperymentalnoho preparatu «Ferosel T». Scientific Messenger LNUVMBT named after S.Z. Gzhytskyj, 19(73), 104-111. doi: 10.15421/nvlvet7322 (in Ukrainian).

Todoriuk, V. B., Hutyi, B. V., Khomyk, R. I., \& Vasiv, R. O. (2016). Vplyv ferrovetu 7,5\% i feroselu $\mathrm{T}$ na kontsentratsiiu mineralnykh rechovyn $\mathrm{v}$ syrovattsi krovi porosiat, khvorykh na 
ferumdefitsytnu anemiiu. Scientific Messenger LNUVMBT named after S.Z. Gzhytskyj, 18, 3(71), 139-143. doi: 10.15421/nvlvet7131 (in Ukrainian).
Vlizlo, V. V. (2012). Laboratorni metody doslidzhen u biolohiyi, tvarynnytstvi ta veterynarniy medytsyni [Laboratory methods of investigation in biology, stock-breeding and veterinary]. Spolom, Lviv (in Ukrainian). 